\title{
Scavenger Receptor Class B type 1 (SR-B1) and the modifiable risk factors of stroke
}

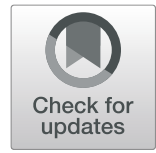

Cameron Lenahan ${ }^{1,2^{*}}$, Lei Huang ${ }^{2,3,4}$, Zachary D. Travis ${ }^{2,5}$ and John H. Zhang 2,3,4,6

\begin{abstract}
Stroke is a devastating disease that occurs when a blood vessel in the brain is either blocked or ruptured, consequently leading to deficits in neurological function. Stroke consistently ranked as one of the top causes of mortality, and with the mean age of incidence decreasing, there is renewed interest to seek novel therapeutic treatments. The Scavenger Receptor Class B type 1 (SR-B1) is a multifunctional protein found on the surface of a variety of cells. Research has found that that SR-B1 primarily functions in an anti-inflammatory and antiatherosclerotic capacity. In this review, we discuss the characteristics of SR-B1 and focus on its potential correlation with the modifiable risk factors of stroke. SR-B1 likely has an impact on stroke through its interaction with smoking, diabetes mellitus, diet, physical inactivity, obesity, hypercholesterolemia, atherosclerosis, coronary heart disease, hypertension, and sickle cell disease, all of which are critical risk factors in the pathogenesis of stroke.
\end{abstract}

Keywords: Scavenger Receptor Class B type 1, SR-B1, Atherosclerosis, Coronary heart disease, Diabetes mellitus, Sickle cell, Obesity, Physical inactivity, Hypercholesterolemia, Hypertension

\section{Background}

Stroke is a devastating disease that affects populations around the world. Stroke is in the top three causes of mortality, and projections expect it to remain there in 2020 [1]. There are two primary categories of stroke: ischemic and hemorrhagic. Ischemic strokes result from clots that obstruct a blood vessel, preventing adequate supply to areas of the brain, and a hemorrhagic stroke occurs due to a ruptured blood vessel, leading to bleeding in the brain. Ischemic stroke comprises $80 \%-85 \%$ of all strokes, and the remaining $15 \%-20 \%$ are comprised of hemorrhagic strokes [2]. Maasz and Melegh state that the majority of ischemic strokes are the result of atherothrombosis $(75 \%)$, whereas the remaining $25 \%$ of cases are from embolisms [2]. The dynamics of stroke epidemiology are rapidly changing. A study published by Feigin et al. regarding the global burden of ischemic and hemorrhagic stroke observed a threefold increase on the global burden from 1990 to 2013 [3]. Once previously considered a disease of the elderly, the incidence is increasing in young adults, thus renewing interest in its

\footnotetext{
* Correspondence: Cameron.Lenahan@mybcom.org

${ }^{1}$ Burrell College of Osteopathic Medicine, Las Cruces, NM 88003, USA

${ }^{2}$ Center for Neuroscience Research, School of Medicine, Loma Linda

University, Loma Linda, CA 92324, USA

Full list of author information is available at the end of the article
}

treatment and prevention [4-6]. A study involving stroke patients from China noted a striking decrease in the mean age of stroke onset in men from 1992 to 2014. In that timeframe, the mean age of stroke among men decreased by 0.28 years, and the incidence of first-ever stroke increased by $12 \%$ among men aged 45-64 [7]. However, Wang et al. did not observe a similar trend among women. Unsurprisingly, the risk factors for stroke in older populations also contribute to a significant proportion of stroke in younger adults [8]. The lifestyle choices of individuals across the globe subject them to an increased risk of stroke. While 9 out of 10 strokes stem from modifiable risk factors, prevention has still proven ineffective [9].

This article will review studies that have explored Scavenger Receptor Class B type 1 (SR-B1)'s role in well-known risk factors for stroke, such as smoking, diabetes mellitus, diet, physical inactivity, obesity, hypercholesterolemia, atherosclerosis, coronary heart disease, hypertension, and sickle cell disease.

\section{Scavenger Receptor Class B type 1}

Research into scavenger receptors has spanned for several decades, with the first scavenger receptor being described in 1979 [10]. The scavenger receptors were

(c) The Author(s). 2019 Open Access This article is distributed under the terms of the Creative Commons Attribution 4.0 International License (http://creativecommons.org/licenses/by/4.0/), which permits unrestricted use, distribution, and 
divided and subdivided into "classes" and "types," based on their sequences and variations in sequences as a result of alternative splicing, respectively [11]. These scavenger receptors are membrane-bound receptors, and while there are similarities in sequence among members of each class, different classes vary significantly in sequence similarity [12].

The class B scavenger receptors include SR-B1, SR-B2 (CD36), and LIMP2 [13]. These receptors are unique, in that they have two transmembrane domains flanking an extracellular loop, with cytoplasmic amino and $C$ termini [13]. Other members of this class have shown promise in suppressing neuroinflammation, such as CD36, which also contributes to hematoma resolution $[14,15]$.

Scavenger Receptor Class B type 1 was identified as the first high-density lipoprotein (HDL) receptor, and it was shown to participate in the selective transport and regulation of cholesterol and lipids [16, 17]. This is significant, as HDL cholesterol levels are shown to be inversely correlated with a risk of stroke $[18,19]$. However, ongoing research has uncovered SR-B1's multifunctional capacity in recognizing and interacting with many ligands, including lipoproteins, apoptotic cells, cholesterol esters, phospholipids, proteoglycans, ferritin, and carbohydrates [12, 20, 21]. SR-B1's other diverse functions also include pathogen recognition [22], protective effects against infertility in women [23], and lastly, efferocytosis of apoptotic cells, contributing to its anti-inflammatory characteristics [24]. These receptors are widely dispersed and expressed in various tissue and cell types, such as in the intestines, keratinocytes, epithelial cells, smooth muscle cells, monocytes, macrophages, mast cells, placenta, gallbladder, ocular tissues, endothelial cells, steroidogenic cells, astrocytes, neurons, hepatocytes, and adipocytes [16, 25-33]. The cell types that express SR-B1 and their functions pertaining to stroke and other neurological disorders have been summarized in Table 1 .

Recent research has uncovered anti-inflammatory characteristics of SR-B1 and functions through several pathways. Vascular smooth muscle cells expressing SR-B1 interact with HDL to inhibit p65 expression, a pro-inflammatory signal [37], and further interactions of HDL requires SR-B1 to partially inhibit reactive oxygen species generation [38]. Additionally, SR-B1's role in inflammation is partly related

Table 1 A summary of the cell types that express SR-B1, and their functions pertaining to the pathology of stroke and other neurological disorders

\begin{tabular}{|c|c|c|}
\hline Cell type & Function & Reference \\
\hline Epithelial cells & $\begin{array}{l}\text { - Upregulates wound tissue repair by affecting the } \\
\text { proliferative and migratory properties of keratinocytes } \\
\text { - Regulates ceramide levels and maintain barrier } \\
\text { function of keratinocytes } \\
\text { - Vitamin E uptake might be regulated by SR-B1 in } \\
\text { pneumocytes } \\
\text { - Functions as plasma membrane cholesterol sensor }\end{array}$ & $\begin{array}{l}\text { Muresan et al. [34], Muresan et al. [35], } \\
\text { Kolleck et al. [36], Morel et al. [20] }\end{array}$ \\
\hline Smooth muscle cells & $\begin{array}{l}\text { - rHDL inhibits smooth muscle cell chemokine } \\
\text { expression, p65, and proliferation through SR-B1 } \\
\text { - HDL-associated lysosphinoglipids function to reduce } \\
\text { ROS generation, which requires SR-B1 coordinate } \\
\text { signaling }\end{array}$ & Van der Vorst et al. [37], Tolle et al. [38. \\
\hline Monocytes & $\begin{array}{l}\text { - Subclinical endotoxemia promotes atherosclerosis by } \\
\text { converting monocytes into a persistent inflammatory } \\
\text { state with reduced SR-B1 }\end{array}$ & Geng et al. [39] \\
\hline Macrophages & $\begin{array}{l}\text { - SR-B1 invalidation reduces free-cholesterol-induced } \\
\text { apoptosis and promotes atherosclerosis }\end{array}$ & Galle-Treger et al. [40] \\
\hline Endothelial cells & $\begin{array}{l}\text { - Functions as plasma membrane cholesterol sensor } \\
\text { - Binding of SR-B1 with HDL activates endothelial NO } \\
\text { synthase and stimulates endothelial cell migration } \\
\text { - Apolipoprotein A-1 promotes endothelial repair } \\
\text { through SR-B1 } \\
\text { - SR-B1 acts as a mechanosensor in response to shear } \\
\text { stress } \\
\text { - SR-B1 is involved in transendothelial cholesterol } \\
\text { transport }\end{array}$ & $\begin{array}{l}\text { Saddar et al. [41], Yuhanna et al. 2001, } \\
\text { Seetharam et al. [42], He et al. [43], } \\
\text { Zhang et al. [44], Miao et al. [21] }\end{array}$ \\
\hline Steroidogenic cells & $\begin{array}{l}\text { - Estrogen increases brain SR-B1 levels } \\
\text { - SR-B1 facilitates vasorelaxation pathway via } \\
\text { interactions with DHEA-enriched HDL }\end{array}$ & Srivastava et al. [45], Paatela et al. [46] \\
\hline Astrocytes & $\begin{array}{l}\text {-Impairment of amyloid } \beta \text { uptake in Alzheimer's } \\
\text { correlated with a lower expression of SR-B1 }\end{array}$ & Iram et al. [47] \\
\hline Hepatocytes & - Mediates uptake of HDL-derived cholesterol ester & Acton et al. [17] \\
\hline
\end{tabular}


to its function in facilitating clearance of other lipoproteins, such as low-density lipoproteins (LDL) and very low-density lipoproteins (VLDL) [48]. An increase in LDL plasma levels is recognized by the innate immune system and initiates an inflammatory response at the endothelial wall, where excess LDL is removed [49-51].

Emerging evidence has shown that the biological effect of SR-B1 is involved in multiple modifiable risk factors for stroke. Figure 1 depicts the relationship between primary modifiable risk factors of stroke and SR-B1. It suggests that the net effects of SR-B1 activation may provide a new strategy for stroke prevention/treatment. Table 2 summarizes specific details regarding the relationship that SR-B1 has with each identified modifiable risk factor.

\section{SR-B1 and smoking}

A study by Epstein et al. reported a reduced likelihood of stroke, myocardial infarction (MI), or death over a period of 4.8 years, if patients quit smoking within 6 months after an ischemic stroke or transient ischemic attack (TIA) [70]. The effects of smoking have such an impact that a study by Hou et al. suggested that secondhand smoke increased the risk of death by $10 \%$ for all stroke types [71].

Cigarette smoke has an established record of damaging type II pneumocytes, epithelial cells that are found in lung tissue [72]. Notably, SR-B1 also has an important function in increasing vitamin $\mathrm{E}$ uptake from HDL into type II pneumocytes found within the lung [36]. This is significant, as a recent meta-analysis published by Cheng et al. found evidence that increased vitamin $\mathrm{E}$ intake was associated with a lower risk of stroke [73]. These type II pneumocytes function to secrete surfactant, which serves to reduce surface tension in the lung, which is necessary to prevent alveolar collapse after expiration [74]. This lung surfactant is comprised primarily of phospholipids, with the remainder of the composition consisting of proteins and neutral lipids [75]. Interestingly, another study determined that vitamin $\mathrm{E}$ is an integral component of lung surfactant assembly [76]. Furthermore, cigarette smoke can also alter the surfactant composition and function of this pulmonary surfactant [77]. One study also found that the reduced surfactant production

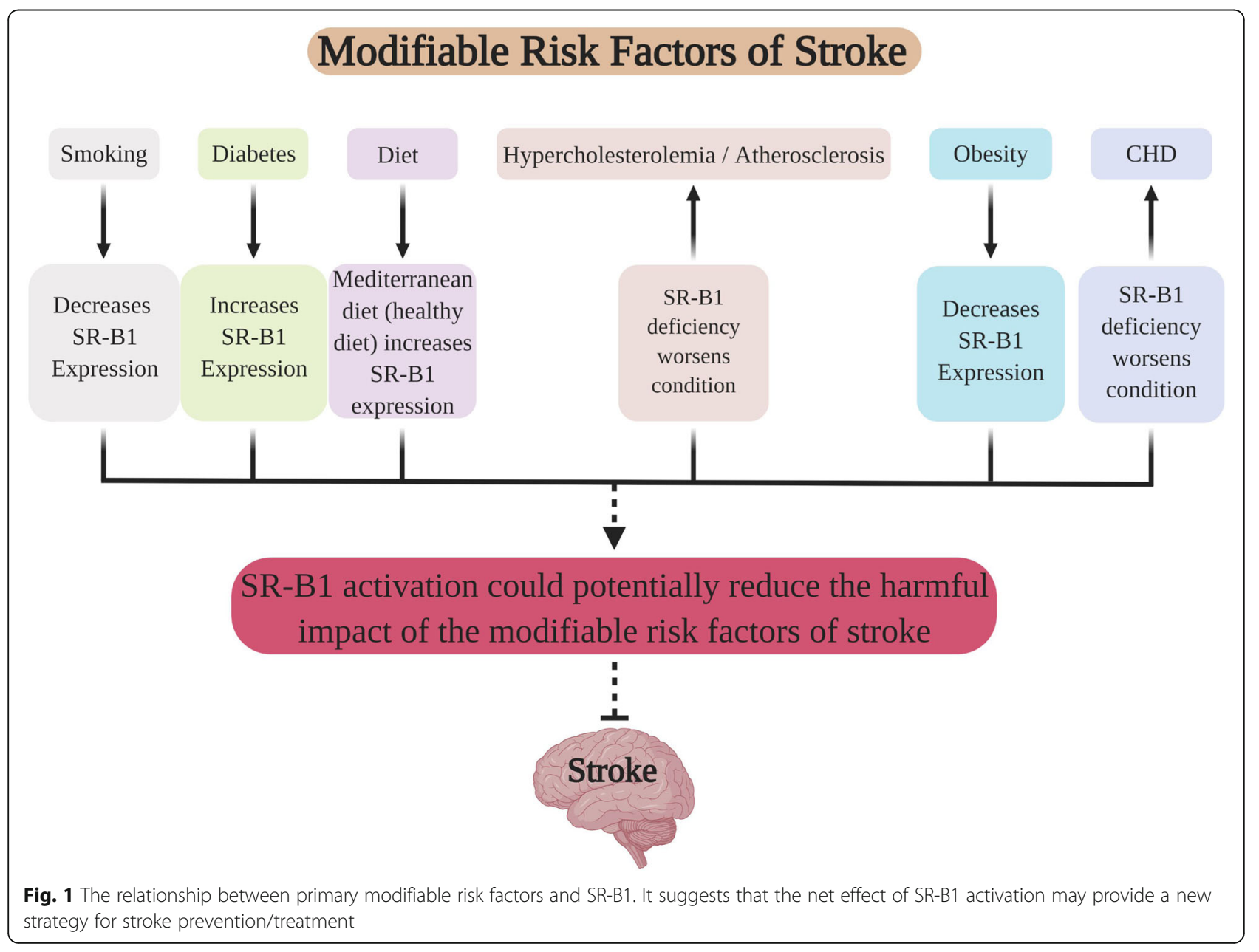


Table 2 A detailed summary depicting the modifiable risk factors and their associated findings

\begin{tabular}{|c|c|c|c|}
\hline SR-B1 & Modifiable risk factors & Findings & References \\
\hline \multirow[t]{2}{*}{ Positive factors } & Diet & $\begin{array}{l}\text { - Mediterranean diet increases SR-B1 expression } \\
\text { - SR-B1 has an important role in the uptake of } \\
\text { lipid-soluble vitamins, which have been } \\
\text { associated with lower risk of stroke } \\
\text { - Chronic moderate alcohol accelerated } \\
\text { cholesterol clearance via SR-B1-mediated reverse } \\
\text { cholesterol transport }\end{array}$ & $\begin{array}{l}\text { Nakamura et al. [52], Rimm et al. [53], } \\
\text { Farras et al. [54], Han et al. [55] } \\
\text { Li et al. [56] }\end{array}$ \\
\hline & Exercise & - Increases SR-B1 expression & Wei et al. [57] \\
\hline \multirow[t]{7}{*}{ Negative factors } & Smoking & $\begin{array}{l}\text { - Smoking decreases SR-B1 expression of } \\
\text { keratinocytes and possibly type II pneumocytes }\end{array}$ & Kolleck et al. [36], Sticozzi et al. [58] \\
\hline & Diabetes & $\begin{array}{l}\text { - Increases SR-B1 expression } \\
\text { - SR-B1-knockout hyperglycemic mice had an } \\
\text { increased incidence of coronary artery } \\
\text { atherothrombosis, myocardial infarction, and } \\
\text { early death }\end{array}$ & Hayashi et al. [59], Gonzalez et al. [60] \\
\hline & Obesity & $\begin{array}{l}\text { - Obesity-induced upregulation of miR-24 could } \\
\text { function as a feedback regulator of SR-B1 }\end{array}$ & Wang et al. [61] \\
\hline & Hypercholesterolemia/atherosclerosis & $\begin{array}{l}\text { - SR-B1 primarily functions in an atheroprotective } \\
\text { capacity, when expressed in monocytes } \\
\text { and macrophages }\end{array}$ & $\begin{array}{l}\text { Kozarsky et al. [62], Zhang et al. [63], } \\
\text { Van Eck et al. [64], Galle-Treger et al. [40] }\end{array}$ \\
\hline & $\begin{array}{l}\text { Coronary heart disease } \\
\text { (CHD) }\end{array}$ & - SR-B1 deficiency leads to increased risk of CHD. & Zanoni et al. [65] \\
\hline & Hypertension & $\begin{array}{l}\text { - Lack of direct studies investigating SR-B1 } \\
\text { expression in hypertension } \\
\text { - Indirect effects may be possible, as a lack of } \\
\text { SR-B1 led to impairment of nitric oxide, a } \\
\text { potent vasodilator }\end{array}$ & Pearson et al. [66], Hermann et al. [67] \\
\hline & Sickle cell & $\begin{array}{l}\text { - No direct studies involving SR-B1 expression } \\
\text { and sickle cell conditions } \\
\text { - Indirect involvement is possible, as lipid } \\
\text { dysregulation partially determines severity of } \\
\text { sickle cell } \\
\text { - SR-B1 is reported to facilitate cell-entry of malaria }\end{array}$ & Akinlade et al. [68], Rodrigues et al. [69] \\
\hline
\end{tabular}

induced by cigarette smoke was restored after the addition of vitamin E [78]. Dysfunction in a pulmonary surfactant caused by cigarette smoke unsurprisingly contributes to pathological dysfunction in other conditions of the lung as well, such as chronic obstructive pulmonary disease (COPD) [77, 79]. Additionally, a recent article suggests that COPD could contribute to the pathogenesis of stroke [80]. This avenue could be an area of interest in the future to determine if SR-B1's role in facilitating vitamin E uptake in type II pneumocytes, which is then used to create pulmonary surfactant, plays a protective role in the presence of risk factors.

Additionally, cigarette smoke not only affects the lungs, but also the skin as well. It particularly affects keratinocytes, cells that function as a protective barrier against environmental damage [35]. Other skin conditions, such as psoriasis, which involves dysregulation of keratinocytes, have already been correlated with stroke [81]. Cholesterol comprises $25 \%$ of the outer layer of skin, known as the stratum corneum [58], and the SR-B1 receptor is also located on keratinocytes [34]. A study found that cigarette smoke dramatically decreased the expression of SR-B1 on keratinocytes. This decreased expression could contribute to an imbalance in cholesterol homeostasis. Their results suggested that the hydrogen peroxide found in cigarette smoke played a prominent role in the decreased expression of SR-B1 [58]. An in vitro study in 2018 also confirmed SR-B1's role in modulating epidermal wound closure. The results suggested a new role for SR-B1, as a possible modulator of keratinocyte proliferation and migration via downregulation of nuclear cyclin D1 and active matrix metalloproteinase-9 expression [34]. Further evidence to support this claim was presented in a study by $\mathrm{He}$ et al., in which an apolipoprotein A-1 (Apo-A1) mimetic, known as 4F, acts on SR-B1 to promote endothelial repair, proliferation, and re-endothelialization in a carotid artery electric injury model [43].

After evaluating the evidence of the studies listed above, it is possible that a risk of stroke induced by smoking could be increased due to smoking's harmful effects on SR-B1. Furthermore, SR-B1's demonstrated function of injury repair on epithelial cells, such as keratinocytes, could also potentially 
contribute to the vascular repair of endothelial cells. More research is warranted to confirm this possible relationship.

\section{SR-B1 and diabetes mellitus}

In the USA, diabetes is the seventh leading cause of death, and $65 \%$ of these deaths are attributable to cardiovascular disease, stroke, or both [82]. Globally, it is the third highest risk factor for premature mortality, and the cost of diabetes exceeds $\$ 174$ billion USD [83, 84]. There are two types of diabetes mellitus, types 1 and 2 . Type 1 diabetes mellitus is often considered a childhood illness, but the vast majority of the type 1 diabetics are adults [85]. As we learn more about type 1 diabetes, we begin to understand that it is more complex than we previously realized. It was once considered a single autoimmune disorder, but has now demonstrated that a variety of factors play an important role in type 1 diabetes, such as environmental factors, metabolism, immune systems, genome, and microbiome [86]. Type 2 diabetes is a global epidemic characterized by insulin resistance and is driven by modifiable risk factors, such as obesity, diet, and sedentary lifestyles, but is also subject to genetic predispositions and epigenetics [87]. In fact, stroke occurs twice as often in people with diabetes, compared to people without diabetes [88].

Unfortunately, both type I and type II diabetes lead to risk factors that contribute to stroke, as type I diabetics are more prone to hypertension, coronary heart disease, peripheral arterial disease, and stroke attributable to small-vessel disease [89]. Whereas, type II diabetics are more likely to have obesity, peripheral arterial disease, history of transient ischemic attack, and stroke attributable to large-artery atherosclerosis [89]. In a recent study, Gonzalez et al. [60] used streptozocin to induce hyperglycemia in SR-B1-knockout/hypoE mice. They reported that the SR-B1-knockout/hypoE hyperglycemic mice had an increased incidence of coronary artery atherothrombosis, myocardial infarction, and early death when on a high-fat, high-cholesterol diet [60]. SR-B1 was increased in type 2 diabetes patients, but not in those with hypercholesterolemia [90]. SR-B1 is upregulated in animal models of diet-induced insulin resistance [59].

Insulin induced a redistribution of SR-B1 from the cytoplasm to a predominantly perinuclear localization [59]. Hayashi et al. proposed the notion that this relocation of SR-B1 into the intracellular membranes is likely critical in SR-B1 function [59]. Their study found that response to the insulin-resistant state, thus leading to overproduction of intestinal apolipoprotein B48-containing particles. The significance of this is attributed to a recent study, in which the evidence suggested an increased fasting plasma apolipoprotein B48 as a risk factor for large artery atherosclerotic stroke [91].

These results suggest that SR-B1 could be upregulated in response to an insulin-resistant state, which may function as a protective mechanism for diabetes-induced complications.

\section{SR-B1 and diet}

Diets play a fundamental role in the risk of stroke, heavily influencing it $[92,93]$. Individuals who have western dietary patterns, which are associated with excessive saturated fats, processed grains, and simple sugars, are at an increased risk of stroke [94]. Conversely, other diets, such as the Mediterranean diet, have been shown to have the opposite effect. A Mediterranean diet consisting of staples such as fish, olive oil, fruits, vegetables, whole grains, legumes/nuts, and moderate alcohol consumption, as described by Widmer et al. [95], has been shown to significantly reduce the risk of stroke by more than $60 \%[96,97]$.

Not surprisingly, the consumption of fish and alcohol, as well as regular exercise, are positively associated with HDL levels [52, 53, 98, 99]. Interestingly, olive oil and beans have also demonstrated effects in upregulating SR-B1 expression [54, 55, 100]. However, the effect of moderate alcohol use on stroke is still controversial. Alcohol has received mixed results pertaining to its risk associated with stroke. There have been documented effects of chronic moderate alcohol intake and its effect on SR-B1. Li et al. suggested that chronic moderate alcohol accelerated cholesterol clearance via SR-B1-mediated reverse cholesterol transport [56]. In this scenario, SR$\mathrm{B} 1$ acts in a peroxisome proliferator-activated receptor gamma (PPAR $\gamma)$-dependent manner, which coincides with other research regarding PPAR's role in the regulation of lipid metabolism and insulin resistance [101].

An important function of the SR-B1 receptor involves the transport of lipid-soluble vitamins, $\mathrm{K}, \mathrm{A}, \mathrm{D}$, and $\mathrm{E}$. For several decades, vitamin $\mathrm{K}$ antagonists have been used extensively in the prevention of stroke, so it may seem counter-intuitive to consider promoting SR-B1, considering its role in the uptake of lipid-soluble vitamins. However, recent research suggests that SR-B1 may be a minor contributor to vitamin $\mathrm{K}$ absorption [102]. While a study by Jeyakumar et al. found that obese rats receiving normal levels of vitamin $\mathrm{A}$ in their diet showed high serum HDL and decreased hepatic SR-B1 expression levels when compared to their lean counterparts, SR-B1 was upregulated in the obese rats with a diet chronically supplemented with vitamin A [103]. Interestingly, 9-cis retinoic acid, a metabolite of vitamin $\mathrm{A}$, has been shown to induce the expression of SR-B1 [104] and recently demonstrated a neuroprotective effect in a rat model of distal middle cerebral artery occlusion [105]. This study found that 9-cis retinoic acid significantly reduced body asymmetry, reduced neurological symptoms, and improved locomotor function in the rats after stroke. Other studies also support the notion that some lipidsoluble vitamins may offer benefits in stroke prevention or treatment. For example, vitamin D protects against atherosclerosis in settings of hypercholesterolemia [106]. As 
previously stated, SR-B1 is involved in vitamin E uptake in type II pneumocytes, but it also contributes to vitamin $\mathrm{E}$ transport across enterocytes [107], and a recent metaanalysis conducted by Cheng et al. has found that increased dietary vitamin $\mathrm{E}$ intake correlates with a reduced risk of stroke [73].

These studies suggest that many benefits of the Mediterranean diet could be mediated through SR-B1 activity. The multifunctional capacity of SR-B1 upregulation in lipid and cholesterol metabolism could potentiate its application for the treatment and prevention of stroke.

\section{SR-B1 and physical inactivity/obesity}

Obesity is associated with a progressively increasing risk of ischemic stroke [108]. The epidemiology of obesity is unique, in that the epidemiology of obesity affects either middle-aged adults or all populations equally in lowincome countries and high-income countries, respectively [109]. The scale of body weight is quantified as a body mass index (BMI). It is categorized as healthy weight, $18.5-24.9 \mathrm{~kg} / \mathrm{m}^{2}$; overweight, $25.0-29.9 \mathrm{~kg} / \mathrm{m}^{2}$; and obese, $>30 \mathrm{~kg} / \mathrm{m}^{2}$. Unfortunately, some researchers expect the prevalence for being overweight and obese to reach dramatic levels in the upcoming years. For example, Keaver et al. [110] proposed that the overweight and obesity prevalence will reach $89 \%$ and $85 \%$ in males and females, respectively, by 2030 in Ireland [110]. Wang et al. showed that obesity-induced upregulation of miR24 could function as a feedback regulator of SR-B1 in obesity [61]. Surprisingly, miR-24 induced different responses from SR-B1, depending on the cell type in which the receptor was located. It repressed HDL uptake in steroidogenic cells, but attenuated HDL uptake, lipid accumulation, and triglyceride levels in HepG2 cells [61]. Conversely, another study described a twofold to threefold increase in SR-B1 expression in exercising animals [57].

Obesity-induced repression of SR-B1 expression in some cells could potentially contribute to other risk factors. The findings that exercising upregulated SR-B1 expression, offers further support for the beneficial role of this receptor [57].

\section{SR-B1 and hypercholesterolemia/atherosclerosis}

Hypercholesterolemia is a recognized causative agent in the development of atherosclerosis [111], a major risk factor for stroke [112]. Ongoing research has revealed a potential Janus-faced role of SR-B1 on atherosclerosis. Researchers have extensively studied the association between SR-B1 and cholesterol. Numerous studies suggest that SR-B1 has an inverse correlation with atherosclerosis [62-64, 113]. In fact, plasma-free cholesterol levels have increased sevenfold in SR-B1-knockout mice [114]. Other studies have suggested that mice deficient in SR-B1 have accelerated aortic sclerosis [40]. However, a recent article suggests that SR-B1 may have polarizing roles in atherosclerosis. Huang et al. presented a study implying that SR-B1 drives endothelial cell LDL transcytosis through a dynamic partnership with dedicator of cytokinesis 4, which will promote atherosclerosis [33]. Conversely, this same study provided conflicting information, in which they also found that the selective silencing of SRB1 expression in hepatocytes resulted in more severe atherosclerosis and early death [33]. Likewise, Geng et al. suggest that in situations of chronic inflammation, monocytes can be programmed in a persistent state of inflammation, notably with reduced SR-B1 [39].

Propofol, a drug commonly used to induce and maintain anesthesia during surgery, has demonstrated antiinflammatory characteristics, by decreasing free radical production [115]. A recent study demonstrated that propofol may promote expression of SR-B1 in macrophages via an enhancement of the PPAR $\gamma /$ liver X receptor alpha $(\mathrm{LXR} \alpha)$ signaling pathway, suggesting that propofol could partially act via SR-B1 upregulation in the potential treatment of atherosclerosis [116].

Consequently, there are plenty of studies suggesting an atheroprotective role of SR-B1 activation, particularly in hepatocytes. Perhaps there is a positive systemic effect in its role in atherosclerosis. These studies appear to suggest that SR-B1's role in atherosclerosis serves primarily in a protective capacity.

\section{SR-B1 and coronary heart disease/hypertension}

Coronary heart disease (CHD) is the primary disease affecting the heart and is well-established as a critical burden on public health in developed countries [117-119]. Globally, hypertension occurs most frequently as a modifiable risk factor for stroke, in countries that are both developed and developing [120]. A study conducted in 2016 suggests an increased risk for $\mathrm{CHD}$ is associated with a genetic deficiency of SR-B1 [65]. Pearson et al. conducted a study with very intriguing results regarding SR-B1 and coronary dysfunction [66]. They explored the effects on the vasculature in mice that lacked the SR-B1, but also had hypomorphic apolipoprotein $\mathrm{E}$ while on a short-term high-fat Paigen diet. Furthermore, they found that the knockout of SR-B1 on endothelial cells with multiple diffuse coronary lesions displayed evidence that there was impairment of local vascular smooth muscle function. Ultimately, their results suggest that a lack of SR-B1 led to impairment of nitric oxide-mediated dilation of conductance and micro-vessels [66]. Hermann et al. elucidated on the fact that impaired nitric oxide bioactivity plays an important role in hypertension and cardiovascular disease [67]. Considering nitric oxide's role as a potent vasodilator, there has not been any research published that directly explores the potential association between SR-B1 
and hypertension. Further research is necessary to determine if a similar relationship exists between SR-B1 and hypertension.

\section{SR-B1 and sickle cell disease}

Sickle cell disease is a widespread condition with a potentially severe prognosis. It has been well-established as a protective trait against malaria and is one of the most common severe monogenic disorders of the world [121, 122]. It is inherited in an autosomal recessive pattern, but has the severity is highly variable. This is in part due to the genetic variations that control hemoglobin F-gene expression, as well as the coinheritance of $\alpha$-thalassemia gene [123]. Approximately 312,000 neonates are homozygous for hemoglobin $S$, the most common and clinically significant structural variant of hemoglobin and is responsible for the symptoms of sickle cell [124]. However, a study in 2014 confirmed that sickle cell patients undergoing a vaso-occlusive crisis had defective lipid metabolism [68]. Low levels of Apo-A1, a major structural apolipoprotein of HDL, also plays a role in the development of pulmonary arterial hypertension, a critical complication of sickle cell disease [125]. Regarding a possible connection between SR-B1 and sickle cell disease, it has been suggested that SR-B1 facilitates Plasmodium infection, and has been proposed as a potential target in malaria prophylaxis $[69,126]$. However, there is a lack of published research to document whether a relationship, if any, is present between SR-B1 and sickle cell disease. There is insufficient evidence to conclusively suggest that SR-B1 is impacted by sickle cell.

\section{Conclusion}

SR-B1 is a complex receptor affected by many comorbidities associated with stroke. The current literature shows that SR-B1 has both positive and negative effects. Some of the risk factors, such as smoking and obesity, act to inhibit the activity of SR-B1, whereas other studies of modifiable risk factors, such as diabetes, hypercholesterolemia, atherosclerosis, and CHD, suggest that a lack of this receptor exacerbates the condition. Interestingly, Mediterranean diets, exercise, and diabetes promote its activity. It is possible that an upregulation in diabetes could be acting as an endogenous protective response, but more research is necessary to validate this speculation. Although we presented evidence for possible indirect involvement with hypertension and sickle cell, it is to be noted that there is a lack of research defining a specific association between SR-B1 and other risk factors for stroke, such as hypertension, atrial fibrillation, peripheral artery disease, and sickle cell.

Considering the extensive involvement of SR-B1 in the various modifiable risk factors of stroke, there is likelihood that the net effect of SR-B1 activation may favor the prevention/treatment of stroke (Fig. 1). Further research is warranted to obtain more information regarding SR-B1's role in stroke and determine whether it serves as a common denominator between the various modifiable risk factors.

\section{Abbreviations \\ APO-A1: Apolipoprotein A-1; BMI: Body mass index; CHD: Coronary heart disease; COPD: Chronic obstructive pulmonary disease; HDL: High-density lipoprotein; IFNa: Interferon a; IL-10: Interleukin-10TGF- $\beta$ Transforming growth factor $\beta$; LDL: Low-density lipoprotein; LXRa: Liver X receptor alpha; MI: Myocardial infarction; PPARY: Peroxisome proliferator-activated receptor; ROS: Reactive oxygen species; SR-B1: Scavenger Receptor Class B type 1; TIA: Transient ischemic attack; VLDL: Very low-density lipoprotein}

\section{Acknowledgements}

Figure 1 was created using BioRender.com

\section{Authors' contributions}

$\mathrm{CL}$ drafted the manuscript. $\mathrm{LH}$ and $\mathrm{ZDT}$ helped revise the manuscript. $\mathrm{CL}, \mathrm{LH}$, ZDT, and JHZ conceived of this study. All authors read and approved the final manuscript.

\section{Funding \\ Funding supported by NIH R01NS103822 to JH Zhang.}

Availability of data and materials

Not applicable

Ethics approval and consent to participate

Not applicable

\section{Consent for publication}

Not applicable

\section{Competing interests}

The authors declare that they have no competing interests.

\section{Author details}

${ }^{1}$ Burrell College of Osteopathic Medicine, Las Cruces, NM 88003, USA.

${ }^{2}$ Center for Neuroscience Research, School of Medicine, Loma Linda

University, Loma Linda, CA 92324, USA. ${ }^{3}$ Department of Neurosurgery, School of Medicine, Loma Linda University, Loma Linda, CA 92350, USA.

${ }^{4}$ Department of Physiology \& Pharmacology, School of Medicine, Loma Linda University, Loma Linda, CA 92350, USA. ${ }^{5}$ Department of Earth and Biological Sciences, School of Medicine, Loma Linda University, Loma Linda, CA 92350, USA. ${ }^{6}$ Department of Anesthesiology, School of Medicine, Loma Linda University, Loma Linda, CA 92324, USA.

Received: 29 August 2019 Accepted: 30 October 2019

Published online: 17 December 2019

\section{References}

1. Smajlovic D. Strokes in young adults: epidemiology and prevention. Vasc Health Risk Manag. 2015;11:157-64.

2. Maasz A, Melegh B. Three periods of one and a half decade of ischemic stroke susceptibility gene research: lessons we have learned. Genome Med. 2010;2(9):64.

3. Feigin VL, Krishnamurthi RV, Parmar P, Norrving B, Mensah GA, Bennett DA, et al. Update on the global burden of ischemic and hemorrhagic stroke in 1990-2013: the GBD 2013 study. Neuroepidemiology. 2015;45(3):161-76.

4. Kissela BM, Khoury JC, Alwell K, Moomaw CJ, Woo D, Adeoye O, et al. Age at stroke: temporal trends in stroke incidence in a large, biracial population. Neurology. 2012;79(17):1781-7.

5. Kittner SJ, Singhal AB. Premature atherosclerosis: a major contributor to early-onset ischemic stroke. Neurology. 2013;80(14):1272-3.

6. Wang $Y$, Rudd AG, Wolfe CD. Age and ethnic disparities in incidence of stroke over time: the South London Stroke Register. Stroke. 2013;44(12): 3298-304. 
7. Wang J, Bai L, Shi M, Yang L, An Z, Li B, et al. Trends in age of first-ever stroke following increased incidence and life expectancy in a low-income Chinese population. Stroke. 2016;47(4):929-35.

8. Aigner A, Grittner U, Rolfs A, Norrving B, Siegerink B, Busch MA. Contribution of established stroke risk factors to the burden of stroke in young adults. Stroke. 2017:48(7):1744-51.

9. Hill VA, Towfighi A. Modifiable risk factors for stroke and strategies for stroke prevention. Semin Neurol. 2017;37(3):237-58

10. Goldstein JL, Ho YK, Basu SK, Brown MS. Binding site on macrophages that mediates uptake and degradation of acetylated low density lipoprotein, producing massive cholesterol deposition. Proc Natl Acad Sci U S A. 1979; 76(1):333-7.

11. Krieger M. The other side of scavenger receptors: pattern recognition for host defense. Curr Opin Lipidol. 1997;8(5):275-80.

12. Zani IA, Stephen SL, Mughal NA, Russell D, Homer-Vanniasinkam S, Wheatcroft SB, et al. Scavenger receptor structure and function in health and disease. Cells. 2015;4(2):178-201.

13. PrabhuDas MR, Baldwin CL, Bollyky PL, Bowdish DME, Drickamer K, Febbraio $\mathrm{M}$, et al. A consensus definitive classification of scavenger receptors and their roles in health and disease. J Immunol. 2017;198(10):3775-89.

14. Zhang Y, Ding Y, Lu T, Zhang Y, Xu N, McBride DW, et al. Biliverdin reductase-A attenuated GMH-induced inflammatory response in the spleen by inhibiting toll-like receptor-4 through eNOS/NO pathway. J Neuroinflammation. 2018;15(1):118.

15. Flores JJ, Klebe D, Rolland WB, Lekic T, Krafft PR, Zhang JH. PPARgammainduced upregulation of CD36 enhances hematoma resolution and attenuates long-term neurological deficits after germinal matrix hemorrhage in neonatal rats. Neurobiol Dis. 2016;87:124-33.

16. Krieger M. Charting the fate of the "good cholesterol": identification and characterization of the high-density lipoprotein receptor SR-BI. Annu Rev Biochem. 1999;68:523-58.

17. Acton S, Rigotti A, Landschulz KT, Xu S, Hobbs HH, Krieger M. Identification of scavenger receptor SR-BI as a high density lipoprotein receptor. Science. 1996:271(5248):518-20.

18. Reina SA, Llabre MM, Allison MA, Wilkins JT, Mendez AJ, Arnan MK, et al. $\mathrm{HDL}$ cholesterol and stroke risk: the multi-ethnic study of atherosclerosis. Atherosclerosis. 2015;243(1):314-9.

19. Lee JS, Chang PY, Zhang Y, Kizer JR, Best LG, Howard BV. Triglyceride and HDL-C Dyslipidemia and risks of coronary heart disease and ischemic stroke by glycemic dysregulation status: the strong heart study. Diabetes Care. 2017:40(4):529-37.

20. Morel E, Ghezzal S, Lucchi G, Truntzer C. Pais de Barros JP, Simon-Plas F, et al. Cholesterol trafficking and raft-like membrane domain composition mediate scavenger receptor class B type 1-dependent lipid sensing in intestinal epithelial cells. Biochim Biophys Acta Mol Cell Biol Lipids. 2018; 1863(2):199-211

21. Miao L, Okoro EU, Cao Z, Yang H, Motley-Johnson E, Guo Z. High-density lipoprotein-mediated transcellular cholesterol transport in mouse aortic endothelial cells. Biochem Biophys Res Commun. 2015;465(2):256-61.

22. Eyre NS, Drummer HE, Beard MR. The SR-BI partner PDZK1 facilitates hepatitis C virus entry. PLoS Pathog. 2010;6(10):e1001130.

23. Miettinen HE, Rayburn H, Krieger M. Abnormal lipoprotein metabolism and reversible female infertility in HDL receptor (SR-BI)-deficient mice. J Clin Invest. 2001;108(11):1717-22.

24. Shen WJ, Azhar S, Kraemer FB. SR-B1: A unique multifunctional receptor for cholesterol influx and efflux. Annu Rev Physiol. 2018;80:95-116.

25. Alsaleh NB, Persaud I, Brown JM. Silver nanoparticle-directed mast cell degranulation is mediated through calcium and PI3K signaling independent of the high affinity lgE receptor. PLoS One. 2016;11(12):e0167366.

26. Shen WJ, Asthana S, Kraemer FB, Azhar S. Scavenger receptor B type 1: expression, molecular regulation, and cholesterol transport function. J Lipid Res. 2018;59(7):1114-31.

27. Trigatti $B$, Rigotti $A$, Krieger $M$. The role of the high-density lipoprotein receptor SR-BI in cholesterol metabolism. Curr Opin Lipidol. 2000;11(2): 123-31.

28. Connelly MA, Williams DL. Scavenger receptor BI: a scavenger receptor with a mission to transport high density lipoprotein lipids. Curr Opin Lipidol. 2004;15(3):287-95.

29. Azhar S, Reaven E. Scavenger receptor class BI and selective cholesteryl ester uptake: partners in the regulation of steroidogenesis. Mol Cell Endocrinol. 2002;195(1-2):1-26.
30. Azhar S, Leers-Sucheta S, Reaven E. Cholesterol uptake in adrenal and gonadal tissues: the SR-BI and 'selective' pathway connection. Front Biosci. 2003;8:5998-1029

31. Provost AC, Pequignot MO, Sainton KM, Gadin S, Salle S, Marchant D, et al. Expression of SR-BI receptor and StAR protein in rat ocular tissues. C R Biol. 2003:326(9):841-51.

32. Berney E, Sabnis N, Panchoo M, Raut S, Dickerman R, Lacko AG. The SR-B1 receptor as a potential target for treating glioblastoma. J Oncol. 2019;2019: 1805841.

33. Huang L, Chambliss KL, Gao X, Yuhanna IS, Behling-Kelly E, Bergaya S, et al. SR-B1 drives endothelial cell LDL transcytosis via DOCK4 to promote atherosclerosis. Nature. 2019;569(7757):565-9.

34. Muresan XM, Sticozzi C, Belmonte G, Cervellati F, Ferrara F, Lila MA, et al. SR$B 1$ involvement in keratinocytes in vitro wound closure. Arch Biochem Biophys. 2018:658:1-6.

35. Muresan XM, Narzt MS, Woodby B, Ferrara F, Gruber F, Valacchi G. Involvement of cutaneous SR-B1 in skin lipid homeostasis. Arch Biochem Biophys. 2019;666:1-7.

36. Kolleck I, Schlame M, Fechner H, Looman AC, Wissel H, Rustow B. HDL is the major source of vitamin E for type II pneumocytes. Free Radic Biol Med. 1999:27(7-8):882-90.

37. van der Vorst EP, Vanags LZ, Dunn LL, Prosser HC, Rye KA, Bursill CA. Highdensity lipoproteins suppress chemokine expression and proliferation in human vascular smooth muscle cells. FASEB J. 2013;27(4):1413-25.

38. Tolle M, Pawlak A, Schuchardt M, Kawamura A, Tietge UJ, Lorkowski S, et al. $\mathrm{HDL}$-associated lysosphingolipids inhibit NAD(P)H oxidase-dependent monocyte chemoattractant protein-1 production. Arterioscler Thromb Vasc Biol. 2008;28(8):1542-8

39. Geng S, Chen K, Yuan R, Peng L, Maitra U, Diao N, et al. The persistence of low-grade inflammatory monocytes contributes to aggravated atherosclerosis. Nat Commun. 2016;7:13436

40. Galle-Treger L, Moreau M, Ballaire R, Poupel L, Huby T, Sasso E, et al. Targeted invalidation of SR-B1 in macrophages reduces macrophage apoptosis and accelerates atherosclerosis. Cardiovasc Res. 2019.

41. Saddar S, Carriere V, Lee WR, Tanigaki K, Yuhanna IS, Parathath S, et al. Scavenger receptor class B type I is a plasma membrane cholesterol sensor. Circ Res. 2013;112(1):140-51.

42. Seetharam D, Mineo C, Gormley AK, Gibson LL, Vongpatanasin W Chambliss KL, et al. High-density lipoprotein promotes endothelial cell migration and reendothelialization via scavenger receptor-B type I. Circ Res. 2006;98(1):63-72.

43. He D, Zhao M, Wu C, Zhang W, Niu C, Yu B, et al. Apolipoprotein A-1 mimetic peptide $4 \mathrm{~F}$ promotes endothelial repairing and compromises reendothelialization impaired by oxidized HDL through SR-B1. Redox Biol. 2018:15:228-42

44. Zhang Y, Liao B, Li M, Cheng M, Fu Y, Liu Q, et al. Shear stress regulates endothelial cell function through SRB1-eNOS signaling pathway. Cardiovasc Ther. 2016;34(5):308-13.

45. Srivastava RA. Scavenger receptor class B type I expression in murine brain and regulation by estrogen and dietary cholesterol. J Neurol Sci. 2003;210(12):11-8

46. Paatela $\mathrm{H}$, Vihma V, Jauhiainen M, Mervaala E, Tikkanen MJ. Dehydroepiandrosterone fatty acyl esters in high density lipoprotein: interaction with human vascular endothelial cells and vascular responses ex vivo. Steroids. 2011;76(4):376-80.

47. Iram $T$, Trudler D, Kain D, Kanner S, Galron R, Vassar R, et al. Astrocytes from old Alzheimer's disease mice are impaired in Abeta uptake and in neuroprotection. Neurobiol Dis. 2016;96:84-94.

48. Ueda Y, Royer L, Gong E, Zhang J, Cooper PN, Francone O, et al. Lower plasma levels and accelerated clearance of high density lipoprotein (HDL) and non-HDL cholesterol in scavenger receptor class B type I transgenic mice. J Biol Chem. 1999:274(11):7165-71.

49. Tsoupras A, Lordan R, Zabetakis I. Inflammation, not cholesterol, is a cause of chronic disease. Nutrients. 2018:10(5).

50. Catapano AL, Pirillo A, Norata GD. Vascular inflammation and low-density lipoproteins: is cholesterol the link? A lesson from the clinical trials. $\mathrm{Br}$ J Pharmacol. 2017;174(22):3973-85

51. Ma X, Feng Y. Hypercholesterolemia tunes hematopoietic stem/progenitor cells for inflammation and atherosclerosis. Int J Mol Sci. 2016;17(7).

52. Nakamura T, Takebe $K$, Tando Y, Arai Y, Yamada N, Ishii M, et al. Serum fatty acid composition in normal Japanese and its relationship with dietary fish 
and vegetable oil contents and blood lipid levels. Ann Nutr Metab. 1995; 39(5):261-70

53. Rimm EB, Williams $P$, Fosher $K$, Criqui M, Stampfer MJ. Moderate alcohol intake and lower risk of coronary heart disease: meta-analysis of effects on lipids and haemostatic factors. BMJ. 1999;319(7224):1523-8.

54. Farras M, Valls RM, Fernandez-Castillejo S, Giralt M, Sola R, Subirana I, et al. Olive oil polyphenols enhance the expression of cholesterol efflux related genes in vivo in humans. A randomized controlled trial. J Nutr Biochem. 2013;24(7):1334-9.

55. Han KH, Fukushima M, Kato T, Kojima M, Ohba K, Shimada K, et al. Enzymeresistant fractions of beans lowered serum cholesterol and increased sterol excretions and hepatic mRNA levels in rats. Lipids. 2003;38(9):919-24.

56. Li M, Diao Y, Liu Y, Huang H, Li Y, Tan P, et al. Chronic moderate alcohol intakes accelerate SR-B1 mediated reverse cholesterol transport. Sci Rep. 2016;6:33032.

57. Wei C, Penumetcha M, Santanam N, Liu YG, Garelnabi M, Parthasarathy S. Exercise might favor reverse cholesterol transport and lipoprotein clearance: potential mechanism for its anti-atherosclerotic effects. Biochim Biophys Acta. 2005;1723(1-3):124-7.

58. Sticozzi C, Belmonte G, Pecorelli A, Arezzini B, Gardi C, Maioli E, et al. Cigarette smoke affects keratinocytes SRB1 expression and localization via $\mathrm{H} 2 \mathrm{O} 2$ production and HNE protein adducts formation. PLoS One. 2012;7(3):e33592.

59. Hayashi AA, Webb J, Choi J, Baker C, Lino M, Trigatti B, et al. Intestinal SR-BI is upregulated in insulin-resistant states and is associated with overproduction of intestinal apoB48-containing lipoproteins. Am J Physiol Gastrointest Liver Physiol. 2011;301(2):G326-37.

60. Gonzalez L, MacDonald ME, Deng YD, Trigatti BL. Hyperglycemia aggravates diet-induced coronary artery disease and myocardial infarction in SR-B1knockout/ApoE-hypomorphic mice. Front Physiol. 2018;9:1398.

61. Wang M, Li L, Liu R, Song Y, Zhang X, Niu W, et al. Obesity-induced overexpression of miRNA-24 regulates cholesterol uptake and lipid metabolism by targeting SR-B1. Gene. 2018;668:196-203.

62. Kozarsky KF, Donahee MH, Glick JM, Krieger M, Rader DJ. Gene transfer and hepatic overexpression of the $\mathrm{HDL}$ receptor SR-BI reduces atherosclerosis in the cholesterol-fed LDL receptor-deficient mouse. Arterioscler Thromb Vasc Biol. 2000;20(3):721-7.

63. Zhang Y, Da Silva JR, Reilly M, Billheimer JT, Rothblat GH, Rader DJ. Hepatic expression of scavenger receptor class B type I (SR-BI) is a positive regulator of macrophage reverse cholesterol transport in vivo. J Clin Invest. 2005; 115(10):2870-4.

64. Van Eck M, Twisk J, Hoekstra M, Van Rij BT, Van der Lans CA, Bos IS, et al. Differential effects of scavenger receptor BI deficiency on lipid metabolism in cells of the arterial wall and in the liver. J Biol Chem. 2003;278(26):23699-705.

65. Zanoni P, Khetarpal SA, Larach DB, Hancock-Cerutti WF, Millar JS, Cuchel M, et al. Rare variant in scavenger receptor Bl raises $\mathrm{HDL}$ cholesterol and increases risk of coronary heart disease. Science. 2016;351(6278):1166-71.

66. Pearson JT, Yoshimoto M, Chen YC, Sultani R, Edgley AJ, Nakaoka H, et al. Widespread coronary dysfunction in the absence of HDL receptor SR-B1 in an ischemic cardiomyopathy mouse model. Sci Rep. 2017;7(1):18108.

67. Hermann M, Flammer A, Luscher TF. Nitric oxide in hypertension. J Clin Hypertens (Greenwich). 2006;8(12 Suppl 4):17-29.

68. Akinlade KS, Adewale CO, Rahamon SK, Fasola FA, Olaniyi JA, Atere AD. Defective lipid metabolism in sickle cell anaemia subjects in vaso-occlusive crisis. Niger Med J. 2014;55(5):428-31.

69. Rodrigues CD, Hannus M, Prudencio M, Martin C, Goncalves LA, Portugal S, et al. Host scavenger receptor SR-BI plays a dual role in the establishment of malaria parasite liver infection. Cell Host Microbe. 2008;4(3):271-82.

70. Epstein KA, Viscoli CM, Spence JD, Young LH, Inzucchi SE, Gorman M, et al. Smoking cessation and outcome after ischemic stroke or TIA. Neurology. 2017;89(16):1723-9.

71. Hou L, Han W, Jiang J, Liu B, Wu Y, Zou X, et al. Passive smoking and stroke in men and women: a national population-based case-control study in China. Sci Rep. 2017;7:45542.

72. Wirtz HR, Schmidt M. Acute influence of cigarette smoke on secretion of pulmonary surfactant in rat alveolar type II cells in culture. Eur Respir J. 1996;9(1):24-32

73. Cheng P, Wang L, Ning S, Liu Z, Lin H, Chen S, et al. Vitamin E intake and risk of stroke: a meta-analysis. Br J Nutr. 2018;120(10):1181-8.

74. Veldhuizen EJ, Haagsman HP. Role of pulmonary surfactant components in surface film formation and dynamics. Biochim Biophys Acta. 2000;1467(2): 255-70.
75. Nkadi PO, Merritt TA, Pillers DA. An overview of pulmonary surfactant in the neonate: genetics, metabolism, and the role of surfactant in health and disease. Mol Genet Metab. 2009;97(2):95-101.

76. Kolleck I, Sinha P, Rustow B. Vitamin E as an antioxidant of the lung: mechanisms of vitamin E delivery to alveolar type II cells. Am J Respir Crit Care Med. 2002;166(12 Pt 2):S62-6.

77. Devendra G, Spragg RG. Lung surfactant in subacute pulmonary disease. Respir Res. 2002;3:19.

78. Xue Y, Williams TL, Li T, Umbehr J, Fang L, Wang W, et al. Type II pneumocytes modulate surfactant production in response to cigarette smoke constituents: restoration by vitamins A and E. Toxicol In Vitro. 2005; 19(8):1061-9.

79. Laniado-Laborin R. Smoking and chronic obstructive pulmonary disease (COPD). Parallel epidemics of the 21 century. Int J Environ Res Public Health. 2009;6(1):209-24.

80. Corlateanu A, Covantev S, Mathioudakis AG, Botnaru V, Cazzola M, Siafakas N. Chronic obstructive pulmonary disease and stroke. COPD. 2018;15(4):405-13.

81. Hawkes JE, Yan BY, Chan TC, Krueger JG. Discovery of the IL-23/LL-17 signaling pathway and the treatment of psoriasis. J Immunol. 2018;201(6): 1605-13.

82. Chen R, Ovbiagele B, Feng W. Diabetes and stroke: epidemiology, pathophysiology, pharmaceuticals and outcomes. Am J Med Sci. 2016; 351(4):380-6.

83. Oguntibeju OO. Type 2 diabetes mellitus, oxidative stress and inflammation: examining the links. Int J Physiol Pathophysiol Pharmacol. 2019;11(3):45-63.

84. Freeman JS. The increasing epidemiology of diabetes and review of current treatment algorithms. J Am Osteopath Assoc. 2010;110(7 Suppl 7):eS2-6.

85. Monaghan M, Helgeson V, Wiebe D. Type 1 diabetes in young adulthood. Curr Diabetes Rev. 2015;11(4):239-50.

86. DiMeglio LA, Evans-Molina C, Oram RA. Type 1 diabetes. Lancet. 2018; 391(10138):2449-62.

87. Zheng Y, Ley SH, Hu FB. Global aetiology and epidemiology of type 2 diabetes mellitus and its complications. Nat Rev Endocrinol. 2018;14(2):8898.

88. Hill MD. Stroke and diabetes mellitus. Handb Clin Neurol. 2014;126:167-74.

89. Putaala J, Liebkind R, Gordin D, Thorn LM, Haapaniemi E, Forsblom C, et al. Diabetes mellitus and ischemic stroke in the young: clinical features and long-term prognosis. Neurology. 2011;76(21):1831-7.

90. Rein-Fischboeck L, Krautbauer S, Eisinger K, Pohl R, Meier EM, Weiss TS, et al. Hepatic scavenger receptor $B$ is associated with type 2 diabetes but unrelated to human and murine non-alcoholic fatty liver disease. Biochem Biophys Res Commun. 2015;467(2):377-82.

91. Tian J, Chen H, Liu P, Wang C, Chen Y. Fasting apolipoprotein B48 is associated with large artery atherosclerotic stroke: a case-control study. Sci Rep. 2019;9(1):3729.

92. Appel LJ, Angell SY, Cobb LK, Limper HM, Nelson DE, Samet JM, et al, Population-wide sodium reduction: the bumpy road from evidence to policy. Ann Epidemiol. 2012;22(6):417-25.

93. Boehme AK, Esenwa C, Elkind MS. Stroke risk factors, genetics, and prevention. Circ Res. 2017;120(3):472-95.

94. Fung TT, Stampfer MJ, Manson JE, Rexrode KM, Willett WC, Hu FB. Prospective study of major dietary patterns and stroke risk in women. Stroke. 2004;35(9):2014-9.

95. Widmer RJ, Flammer AJ, Lerman LO, Lerman A. The Mediterranean diet, its components, and cardiovascular disease. Am J Med. 2015;128(3):229-38.

96. Tsivgoulis G, Psaltopoulou T, Wadley VG, Alexandrov AV, Howard G, Unverzagt FW, et al. Adherence to a Mediterranean diet and prediction of incident stroke. Stroke. 2015;46(3):780-5.

97. Spence JD. Recent advances in preventing stroke recurrence. F1000Res. 2017:6:1017.

98. Nakamura A, Niimura H, Kuwabara K, Takezaki T, Morita E, Wakai K, et al. Gene-gene combination effect and interactions among ABCA1, APOA1, SR$B 1$, and CETP polymorphisms for serum high-density lipoprotein-cholesterol in the Japanese population. PLoS One. 2013;8(12):e82046.

99. Cauley JA, Kriska AM, LaPorte RE, Sandler RB, Pambianco G. A two year randomized exercise trial in older women: effects on $\mathrm{HDL}$-cholesterol. Atherosclerosis. 1987;66(3):247-58.

100. Han KH, Sekikawa M, Shimada K, Sasaki K, Ohba K, Fukushima M. Resistant starch fraction prepared from kintoki bean affects gene expression of genes associated with cholesterol metabolism in rats. Exp Biol Med (Maywood). 2004;229(8):787-92. 
101. Yumuk VD. Targeting components of the stress system as potential therapies for the metabolic syndrome: the peroxisome-proliferator-activated receptors. Ann N Y Acad Sci. 2006;1083:306-18.

102. Yamanashi $Y$, Takada $T$, Kurauchi R, Tanaka Y, Komine T, Suzuki H. Transporters for the intestinal absorption of cholesterol, vitamin $E$, and vitamin K. J Atheroscler Thromb. 2017;24(4):347-59.

103. Jeyakumar SM, Vajreswari A, Giridharan NV. Impact of vitamin A on highdensity lipoprotein-cholesterol and scavenger receptor class BI in the obese rat. Obesity (Silver Spring). 2007;15(2):322-9.

104. Norata GD, Ongari M, Uboldi P, Pellegatta F, Catapano AL. Liver X receptor and retinoic $X$ receptor agonists modulate the expression of genes involved in lipid metabolism in human endothelial cells. Int J Mol Med. 2005;16(4): 717-22.

105. Yu SJ, Airavaara M, Wu KJ, Harvey BK, Liu HS, Yang Y, et al. 9-cis retinoic acid induces neurorepair in stroke brain. Sci Rep. 2017;7(1):4512.

106. Yin K, You Y, Swier V, Tang L, Radwan MM, Pandya AN, et al. Vitamin D protects against atherosclerosis via regulation of cholesterol efflux and macrophage polarization in hypercholesterolemic swine. Arterioscler Thromb Vasc Biol. 2015;35(11):2432-42.

107. Reboul E, Klein A, Bietrix F, Gleize B, Malezet-Desmoulins C, Schneider M, et al. Scavenger receptor class B type I (SR-BI) is involved in vitamin $E$ transport across the enterocyte. J Biol Chem. 2006;281(8):4739-45.

108. Strazzullo P, D'Elia L, Cairella G, Garbagnati F, Cappuccio FP, Scalfi L. Excess body weight and incidence of stroke: meta-analysis of prospective studies with 2 million participants. Stroke. 2010;41(5):e418-26.

109. Swinburn BA, Sacks G, Hall KD, McPherson K, Finegood DT, Moodie ML, et al. The global obesity pandemic: shaped by global drivers and local environments. Lancet. 2011;378(9793):804-14.

110. Keaver L, Webber L, Dee A, Shiely F, Marsh T, Balanda K, et al. Application of the UK foresight obesity model in Ireland: the health and economic consequences of projected obesity trends in Ireland. PLoS One. 2013;8(11): e79827.

111. Kottke BA, Pineda AA, Case MT, Orsuzar AM, Brzys KA. Hypercholesterolemia and atherosclerosis: present and future therapy including LDL-apheresis. J Clin Apher. 1988;4(1):35-46.

112. Nagai $Y$, Kitagawa $K$, Sakaguchi M, Shimizu Y, Hashimoto $H$, Yamagami $H$, et al. Significance of earlier carotid atherosclerosis for stroke subtypes. Stroke. 2001;32(8):1780-5.

113. Zhang W, Yancey PG, Su YR, Babaev VR, Zhang Y, Fazio S, et al. Inactivation of macrophage scavenger receptor class B type I promotes atherosclerotic lesion development in apolipoprotein E-deficient mice. Circulation. 2003; 108(18):2258-63.

114. Guo X, Liao J, Huang X, Wang Y, Huang W, Liu G. Reversal of adipose tissue loss by probucol in mice with deficiency of both scavenger receptor class $B$ type 1 and LDL receptor on high fat diet. Biochem Biophys Res Commun. 2018;497(3):930-6.

115. Brasil L, San-Miguel B, Kretzmann NA, Amaral JL, Zettler CG, Marroni N, et al. Halothane induces oxidative stress and NF-kappaB activation in rat liver: protective effect of propofol. Toxicology. 2006;227(1-2):53-61.

116. Ma X, Li SF, Qin ZS, Ye J, Zhao ZL, Fang HH, et al. Propofol up-regulates expression of $A B C A 1, A B C G 1$, and SR-B1 through the PPARgamma/LXRalpha signaling pathway in THP-1 macrophage-derived foam cells. Cardiovasc Pathol. 2015:24(4):230-5.

117. Wirtz PH, von Kanel R. Psychological stress, inflammation, and coronary heart disease. Curr Cardiol Rep. 2017;19(11):111.

118. Townsend N, Wilson L, Bhatnagar P, Wickramasinghe K, Rayner M, Nichols M. Cardiovascular disease in Europe: epidemiological update 2016. Eur Heart J. 2016;37(42):3232-45.

119. Benjamin EJ, Blaha MJ, Chiuve SE, Cushman M, Das SR, Deo R, et al. Heart disease and stroke statistics-2017 update: a report from the American Heart Association. Circulation. 2017;135(10):e146-603.

120. Pistoia F, Sacco S, Degan D, Tiseo C, Ornello R, Carolei A. Hypertension and stroke: epidemiological aspects and clinical evaluation. High Blood Press Cardiovasc Prev. 2016;23(1):9-18.

121. Rees DC, Williams TN, Gladwin MT. Sickle-cell disease. Lancet. 2010; 376(9757):2018-31

122. Croke K, Ishengoma DS, Francis F, Makani J, Kamugisha ML, Lusingu J, et al. Relationships between sickle cell trait, malaria, and educational outcomes in Tanzania. BMC Infect Dis. 2017;17(1):568.

123. Piel FB, Steinberg MH, Rees DC. Sickle cell disease. N Engl J Med. 2017; 376(16):1561-73
124. Piel FB, Patil AP, Howes RE, Nyangiri OA, Gething PW, Dewi M, et al. Global epidemiology of sickle haemoglobin in neonates: a contemporary geostatistical model-based map and population estimates. Lancet. 2013; 381(9861):142-51.

125. Anjum F, Lazar J, Soh J, Albitar M, Gowda S, Hussain MM, et al. Dysregulation of ubiquitin-proteasome pathway and apolipoprotein A metabolism in sickle cell disease-related pulmonary arterial hypertension. Pulm Circ. 2013;3(4):851-5.

126. Arredondo SA, Swearingen KE, Martinson T, Steel R, Dankwa DA, Harupa A, et al. The micronemal plasmodium proteins P36 and P52 act in concert to establish the replication-permissive compartment within infected hepatocytes. Front Cell Infect Microbiol. 2018;8:413.

\section{Ready to submit your research? Choose BMC and benefit from:}

- fast, convenient online submission

- thorough peer review by experienced researchers in your field

- rapid publication on acceptance

- support for research data, including large and complex data types

- gold Open Access which fosters wider collaboration and increased citations

- maximum visibility for your research: over $100 \mathrm{M}$ website views per year

At $\mathrm{BMC}$, research is always in progress.

Learn more biomedcentral.com/submissions 